\title{
OPTIMIZATION OF ALUMINA FLOTATION FROM GIBBSITE BEARING-SHALE OF SOUTH WESTERN SINAI, EGYPT BY USING SODIUM OLEATE AS A COLLECTOR
}

\author{
M. M. Ahmed ; G. A. Ibrahim ${ }^{b}$; A. A. Elmowafy ${ }^{c}$ and H. G. Ahmed ${ }^{d}$ \\ ${ }^{a, b}$ Mining and Metallurgical Engineering Department, Faculty of Engineering, \\ Assiut University, Assiut 71516, Egypt ${ }^{\text {c, } d}$ Nuclear Materials Authority, Egypt
}

(Received December 12, 2007 Accepted January 8, 2008)

The effect of sodium oleate on the flotation of alumina was studied using samples of gibbsite bearing-shale of south western Sinai, Egypt. The assays of the samples are $18.98 \% \mathrm{Al}_{2} \mathrm{O}_{3}, 15.45 \% \mathrm{SiO}_{2}, 12.83 \% \mathrm{Fe}_{2} \mathrm{O}_{3}$, $14.87 \% \mathrm{CaO}, 5.74 \% \mathrm{P}_{2} \mathrm{O}_{5}, 5.34 \% \mathrm{MnO}, 0.86 \% \mathrm{~K}_{2} \mathrm{O}, 0.76 \% \mathrm{Na}_{2} \mathrm{O}, 1.50 \%$ trace elements and $23.65 \%$ loss on ignition. The aim of this research is to upgrade alumina in the concentrate to be suitable for the industrial applications. Various operating variables (i. e. pH, pulp density, collector dosage, and particle size) affecting the flotation process of gibbsite were studied. Sodium oleate used as an anionic collector; as well as, sodium hydroxide was used as a $\mathrm{pH}$ modifier.

The optimum conditions obtained were as follows: $p H=11$, collector dosage $=2000 \mathrm{~g} / \mathrm{t}$, pulp density $=250 \mathrm{~g} / \mathrm{l}$ and particle size $=(-100+80)$ $\mu \mathrm{m}$. At these conditions, a concentrate having a grade of $40.1 \%$ alumina with component recovery of $96.1 \%$ was obtained. The grades of the other ore constituents in final concentrate were as follows: $\mathrm{SiO}_{2}$ was decreased from $14.2 \%$ to $5.9 \%, \mathrm{CaO}$ was decreased from $14.1 \%$ to $4.8 \%, \mathrm{Fe}_{2} \mathrm{O}_{3}$ was decreased from $13.1 \%$ to $5.4 \%, \mathrm{P}_{2} \mathrm{O}_{5}$ was decreased from $4.3 \%$ to $3.2 \%$, $\mathrm{MnO}$ was decreased from $4.2 \%$ to $3.5 \%$, while $\mathrm{K}_{2} \mathrm{O}$ was increased from $0.89 \%$ to $1.3 \%$, $\mathrm{Na}_{2} \mathrm{O}$ was also increased from $0.69 \%$ to $1.2 \%$, traces were increased from $1.6 \%$ to $2.7 \%$, and loss on ignition was increased from $25.4 \%$ to $31.9 \%$. The component recoveries of $\mathrm{SiO}_{2}, \mathrm{CaO}, \mathrm{Fe}_{2} \mathrm{O}_{3}$, $\mathrm{P}_{2} \mathrm{O}_{5}, \mathrm{MnO}, \mathrm{K}_{2} \mathrm{O}, \mathrm{Na}_{2} \mathrm{O}$, and traces of the final concentrate were $21.4 \%$, $17.5 \%, 21.2 \%, 38.4 \%, 42.9 \%, 75.3 \%, 89.6 \%$, and $86.9 \%$, respectively. The mass recovery of final concentrate was $51.5 \%$.

KEYWORDS: Gibbsite, alumina flotation, collectors, isoelectric point, pH, pulp density, particle size

\section{NOMENCLATURE}

c assay of constituent in concentrate, $\%$

C mass of concentrate, gm

$f \quad$ assay of constituent in feed, $\%$

$F \quad$ mass of feed, gm

$R_{c}(c)$ component recovery of constituent in concentrate, $\%$
$R_{c}(t)$ component recovery of constituent in tailings, $\%$

$R_{m}(c)$ mass recovery of concentrate, $\%$

$R_{m}(t)$ mass recovery of tailings, $\%$

$t$ assay of constituent in tailings, \%

$T$ mass of tailings, gm 


\section{INTRODUCTION}

Gibbsite $\mathrm{Al}(\mathrm{OH})_{3}$ is a crystalline aluminum trihydroxide which is used in the manufacture of refractory products [1]. The most abundant structural element in the earth s crust is aluminium. It composes eight per cent of the earth s mineable layer and is most abundant as aluminium oxide or combined oxides in a wide variety of minerals [2,3]. Due to their high corrosion resistance and mechanical strength to mass ratio, aluminum alloys are used as major structural material in aircraft, buildings, machinery parts, beverage cans and food warps [4,5]. In nature, aluminum occurs only in combination with other elements and is a part of the crystal structure of many rock forming minerals. Bauxite is the most important commercial ore of aluminum [5]. Bauxite consists of several hydrous aluminium oxide phases [boehmite $(\gamma \mathrm{AlO} . \mathrm{OH})$, gibbsite $\left(\mathrm{Al}(\mathrm{OH})_{3}\right)$, and diaspore $(\alpha \mathrm{AlO} . \mathrm{OH})$ [2]. Besides of its main use as an aluminum ore, bauxite is used also to manufacture refractory products, aluminous chemicals, abrasives, and miscellaneous applications. These applications include $\beta$-alumina solid state electrolytes and first-class refractories [4].

The major impurities of gibbsite of south western Sinai are quartz, hematite and kaolinite. Other impurities such as, rare earths and alkali occur in small percentages. Gravity, magnetic, or electrostatic separation methods are not suitable for the concentration of gibbsite ore. This may be due to the very small significant differences in the physical properties (density, magnetic and electrostatic susceptibility, etc.) between the mineral phases (gibbsite, kaolinite and quartz), which are considered the major constituents of the ore. Flotation process was then selected as a suitable and effective method for the concentration and upgrading of alumina from gibbsite bearing-shale of south western Sinai to make it suitable for the Bayer process.

Many researchers [4-13] have studied the flotation of alumina using different types of collectors. Their results are summarized and explained below.

Flotation was selected as the most suitable method for the recovery of a high purity gibbsite concentrate from the Brazilian bauxite ore using alkyl sulfates as collectors. The results were good at $\mathrm{pH}$ value of 2 , where the component recovery of alumina was $97.4 \%$ and the grade of alumina was $93 \%$ at a particle size of $(-177+3)$ $\mu \mathrm{m}$ and a pulp density of $20 \%$ solids [4].

In other research, sodium oleate was used to float gibbsite from a mixture of quartz, kaolinite, iron and titanium oxides (Guyana bauxite ore) at $\mathrm{pH}$ values between 10 and 11. At the optimum conditions a component recovery of more than $90 \%$ gibbsite was obtained [6]. The maximum floatability of gibbsite, chamosite and boehmite was achieved at a $\mathrm{pH}$ of 8 during the adsorption of laurylamine on all minerals. The adsorption of laurylamine occurred at a $\mathrm{pH}$ value ranged between 4 and 8 [7].

However, the flotation of gibbsite by using amines as collectors can not be applied for the south western Sinai gibbsite ore because a significant amount of quartz is present. Bulut and Yurtsever [8] found that, sodium dodecyl sulfate, as an alkyl sulfate collector, is effective in the acidic $\mathrm{pH}$ range during the flotation of alumina from kyanite ore using different collectors. Dodecylamine hydrochloride (DAH), as a cationic collector, is effective in the basic $\mathrm{pH}$ range and potassium oleate (KOL), as an anionic collector, floats kyanite at $\mathrm{pH}$ value ranges from 6 to 9. Doss [9] reported that, anionic surfactants such as the alkyl sulfates and alkyl sulfonates are adsorbed on 
alumina by means of electrostatic and hydrophobic bonding. Consequently, when the alumina surface becomes negatively charged above $\mathrm{pH} 9$, sulphonate adsorption ceases, but at $\mathrm{pH}$ values below 9, sulphonate ions is adsorbed to the positive alumina surface by electrostatic attraction.

Aluminum silicates such as pyrophyllite, illite and kaolinite are impurity minerals in diasporic-bauxite, it being necessary to remove these silicate minerals to improve the mass ratio of $\mathrm{Al}_{2} \mathrm{O}_{3} / \mathrm{SiO}_{2}$ for the Bayer process. Quaternary ammonium salt (DTAL) was used to float diaspore at a $\mathrm{pH}$ values ranged from 6 to 7 [10]. The surface charges of gibbsite particles were probed by potentiometric titration and subsequently were analyzed to estimate intrinsic proton affinity constants of $\mathrm{OH}$ surface groups. It was found that the point of zero charge could be achieved at a $\mathrm{pH}$ value ranged from 8.1 to 9.6 [11]. The electron spin resonance (ESR) was used to study the adsorption of spin probe analogs of stearic acid on amorphous alumina [12].

The point of zero charge (ZPC) of gibbsite is at a $\mathrm{pH}$ value of 9.1. The electrokinetic potential and contact angle measurements were used to show the adsorption mechanism of sodium dodecyl sulfate and dodecylamine chloride on the alumina surface. From these results, it was found that, sodium dodecyl sulfate and dodecylamine chloride converted the alumina surface to a hydrophobic one at a $\mathrm{pH}$ less than ZPC and a pH more than ZPC, respectively [13]. Zhenghe et al. [5] have used the reverse flotation technology to float alumina from alumino silicates using a cationic collector. The purpose of the presented work is to upgrade the alumina in gibbsite ore to be suitable for industerial applications by using of sodium oleate as a flotation collector. These industerial applications include aluminous chemicals, abrasives, building stones, alumina refractories and aluminium extraction [4].

\section{MINERALOGY}

Based on petrography and EDX technique, several minerals were identified in the studied samples as follows:

Gibbsite is turbid cryptocrystalline heavily stained black, orange and brown colors. It occurs as radial aggregate embedded in marly matrix. The matrix is mainly composed of equal amounts of fine-grained quartz and carbonate. It contains minute grains of Fe and Mn oxy-hydroxides. The BSE of gibbsite is shown in Fig. 1.

Quartz is monocrystalline, medium-grained, well sorted and subround to well round. The cryptocrystalline quartz occurs as filling pore spaces between grains and as over growths. The BSE of quartz is shown in Fig. 2.

Kaolin occurs as amorphous dusts and patches with aggregate polarization in crossed nicols. It mostly resulted from acidic ground water, whereas the unstable minerals dissolve releasing $\mathrm{Si}, \mathrm{Al}$ to the pore waters that can be produced by flushing of the gibbsite by fresh water. The BSE of kaolin is shown in Fig. 3.

Halite appears as disseminated small cubic crystals encountered in gibbsite. Calcite occurs as rhombohedral crystals, anhedral grains and aggregates radiating fibrous. It exhibits twinning and perfect rhombohedral cleavages.

Hematite occurs either as disseminated anhedral crystals or occasionally as minutes. It is steel-black with metallic luster in reflected light with a tendency to a marginal red. Generally, the iron associated with manganese forming Mn-Fe minerals. 




Fig. 1: The BSE image of gibbsite

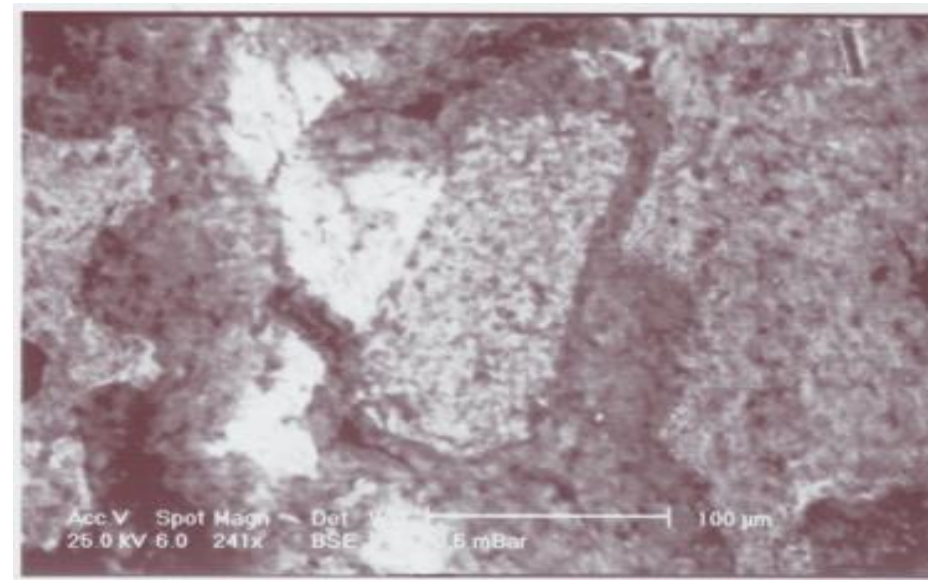

Fig. 2: The BSE image of quartz

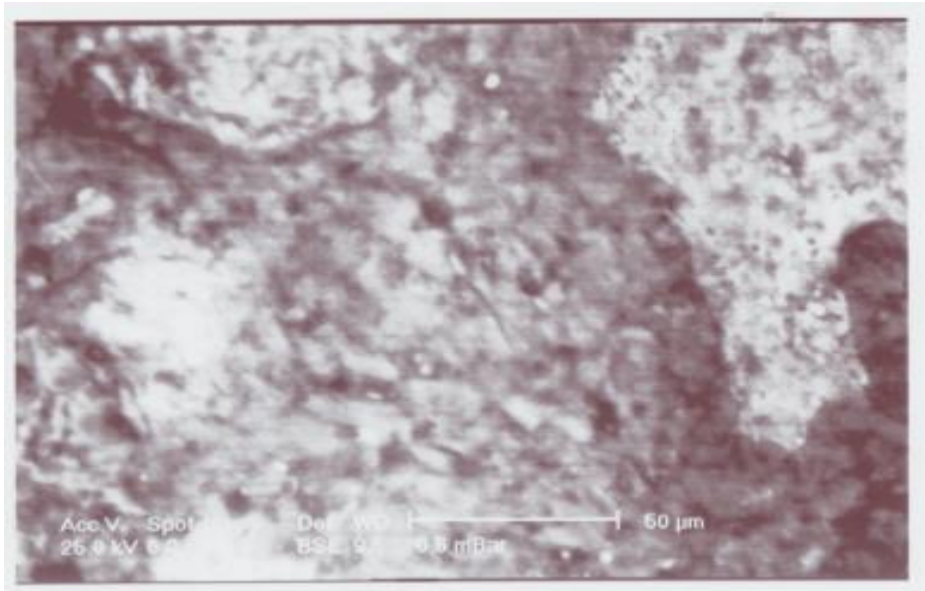

Fig. 3: The BSE image of kaolin 
Gypsum exists as white massive and acicular prismatic crystals of different shape and sizes. They exhibit aggregates of subhedral to anhedral crystals having vitreous luster. Few crystals show the perfect cleavage of the growing crystals. The occurrence of gypsum in the studied gibbsite can be explained as due to upward movement of brine by capillary action and its evaporation at the surface.

\section{EXPERIMENTAL WORK}

\subsection{Materials}

The samples used in the present work were obtained from the Southwest of Sinai (Abu Thur). A batch representative sample of about $250 \mathrm{~kg}$ was taken from the gibbsite zone. The obtained sample was split to smaller ones and crushed to minus $10 \mathrm{~mm}$ in a laboratory jaw crusher. The crusher product was sieved on a screen of $200 \mu \mathrm{m}$ size. The screen oversize $(+200 \mu \mathrm{m})$ was ground in a closed ball mill to minus $200 \mu \mathrm{m}$. Grinding conditions were as follows: slope of mill $=0^{\circ}$, ball-to-ore ratio $=3: 1$, mill speed $=60 \mathrm{rpm}$, and grinding time $=20$ minutes. The crushing and grinding flowsheet of the head sample is illustrated in Fig. 4.

A representative sample was taken and chemically analyzed for the determination of the different constituents. The chemical analysis of the studied head sample is given in Table 1

\subsection{Reagents}

All the flotation tests were carried out using sodium oleate as a collector. Sodium hydroxide was used as a $\mathrm{pH}$ modifier. Tap water was used for maintaining the flotation pulp at a constant level, as well as, all the other experimental purposes.

\subsection{Apparatus}

Laboratory flotation tests were carried out in a $3000 \mathrm{ml}$ Wemco Fagergern cell. A hand skimming was used to skim the froth.

\subsection{Experimental Procedures}

The impeller speed, during all flotation tests, was fixed at $1250 \mathrm{rpm}$ and an aeration rate of $6 \mathrm{~L} / \mathrm{min}$ was used. The total conditioning time was $15 \mathrm{~min}$. The studied operating parameters were the $\mathrm{pH}$ value, collector dosage, pulp density and feed particle size. The gibbsite sample was added slowly and then conditioned with water for 5 minutes.

The $\mathrm{pH}$ value was adjusted at the end of the initial conditioning period and allowed to condition for 5 minutes with the pulp. The collector dosage was added at the end of the second conditioning period and allowed to condition for 5 min with the pulp prior the aeration. The air supply valve was gradually opened. The required pulp level was maintained constant during the flotation experiments.

In each experiment, and after allowing $15 \mathrm{sec}$ for the froth to form, one concentrate was collected during batch flotation tests. The collected products 
(concentrate and tailings) were dried, weighed and chemically analyzed. The component recovery of alumina and other constituents in the concentrate and tailings were calculated.

\section{R.O.M}

Gibbsite ore

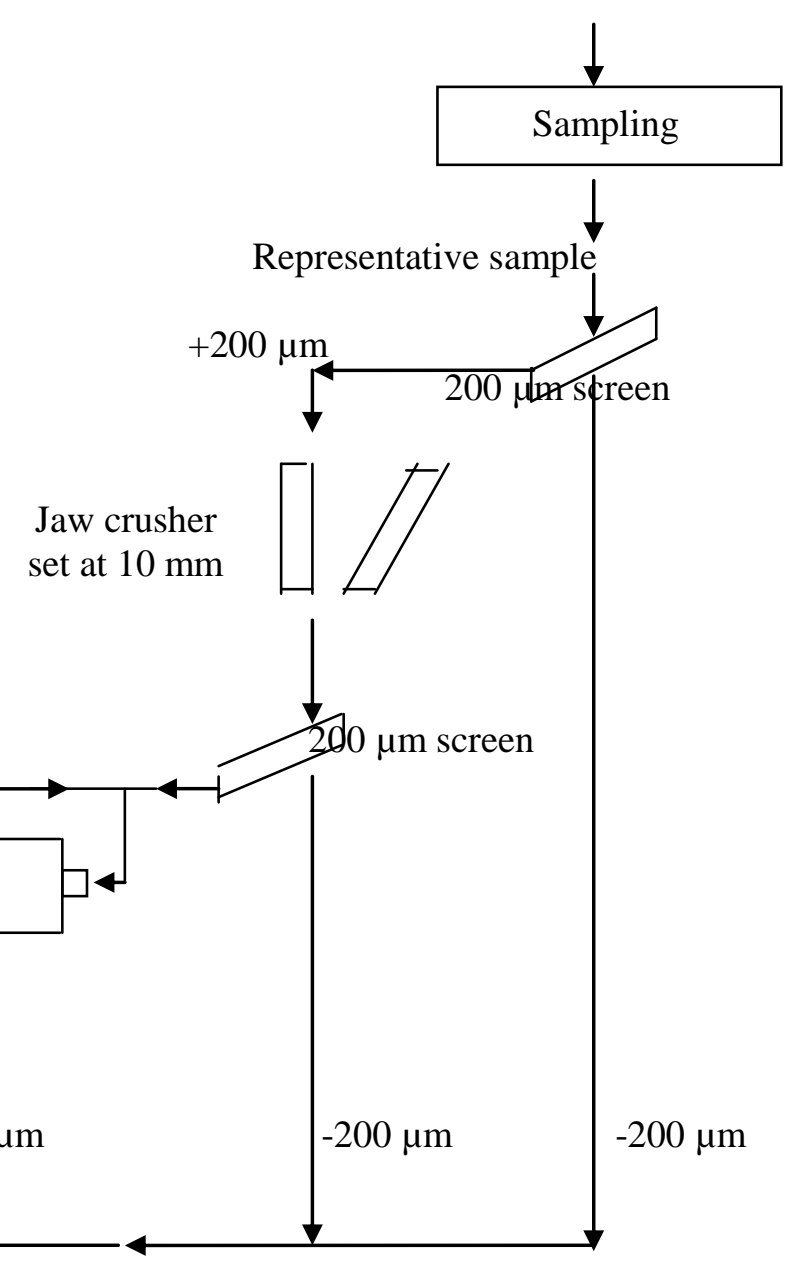

To flotation process

Fig. 4: Crushing \& grinding flow-sheet of the head sample

Table 1: Chemical analysis of the head sample of gibbsite ore from South Western Sinai (Abuthur)

\begin{tabular}{|l|l|l|l|l|l|l|l|l|l|l|}
\hline $\mathrm{Al}_{2} \mathrm{O}_{3} \%$ & $\mathrm{SiO}_{2} \%$ & $\mathrm{Fe}_{2} \mathrm{O}_{3} \%$ & $\mathrm{CaO}_{2}$ & $\mathrm{P}_{2} \mathrm{O}_{5} \%$ & $\mathrm{MnO}_{0}$ & $\mathrm{~K}_{2} \mathrm{O} \%$ & $\mathrm{Na}_{2} \mathrm{O} \%$ & Traces\% & L.O.I.\% & Total\% \\
\hline 18.98 & 15.45 & 12.83 & 14.87 & 5.74 & 5.34 & 0.86 & 0.76 & 1.50 & 23.65 & 99.98 \\
\hline
\end{tabular}




\section{RESULTS AND DISCUSSION}

\subsection{Calculations of Experimental Mass and Component Recovery of Flotation products}

Using the mass percent and assays of alumina in feed, concentrate, and tailings, the experimental value of the mass recovery and component recovery of alumina in concentrate and tailings can be calculated as follows:

$$
\begin{aligned}
& \text { Mass recovery of concentrat } \mathrm{e}=\mathrm{R}_{\mathrm{m}}(\mathrm{c})=100 \cdot \frac{\mathrm{C}}{\mathrm{F}} \\
& \text { Mass recovery of tailings }=\mathrm{R}_{\mathrm{m}}(\mathrm{t})=100 \cdot \frac{\mathrm{T}}{\mathrm{F}} \\
& \text { Component recovery in concentrat } \mathrm{e}=\mathrm{R}_{\mathrm{c}}(\mathrm{c})=100 . \frac{\mathrm{C} . \mathrm{c}}{\mathrm{F} . \mathrm{f}} \\
& \text { Component recovery in tailing } \mathrm{s}=\mathrm{R}_{\mathrm{c}}(\mathrm{t})=100 . \frac{\mathrm{T} . \mathrm{t}}{\mathrm{F} . \mathrm{f}}
\end{aligned}
$$

\subsection{Results of Using Sodium oleate as a Collector}

\subsubsection{Effect of $\mathrm{pH}$ value}

Table 2 and Figure 5a show the effect of $\mathrm{pH}$ value on the grade, component recovery of alumina in the concentrate, and the mass recovery of concentrate. These experiments were carried out at a particle size of $-200 \mu \mathrm{m}$, pulp density of $150 \mathrm{~g} / \mathrm{l}$, and collector dosage of $1500 \mathrm{~g} / \mathrm{t}$. From this figure, it is noticed that the best selectivity is achieved at a $\mathrm{pH}$ value of 11 , where the component recovery of alumina in concentrate was $78.3 \%$, the alumina grade was $40.1 \%$, and the mass recovery of concentrate was about $37.1 \%$. The grade of alumina decreases from $38.1 \%$ at a $\mathrm{pH}$ value of 6 to $33.5 \%$ at a $\mathrm{pH}$ value of 9 , then increases at higher $\mathrm{pH}$ value.

The zero point charge of gibbsite is at $\mathrm{pH}$ values of (8.1-9). Below these values, the gibbsite surface is positively charged, thus, negatively charged ions of any anionic collector may be potentially adsorbed in this $\mathrm{pH}$ range [13]. Above the zero point charge value, the surface of gibbsite is negatively charged, so ions of any anionic collector are repelled from the gibbsite surface. Sodium oleate $(\mathrm{C} 17 \mathrm{H} 33 \mathrm{COONa})$ is an alkali soap of oleic acid. Although sodium oleate is an anionic collector, it floats gibbsite above the isoelectric point of gibbsite. This indicates that, chemisorption rather than the electrostatic interaction occurs between the oleate anion and gibbsite surface $[14,15]$.

The isoelectric point of alumina shifts in the presence of sodium oleate and this shift of the isoelectric point of gibbsite is attributed to the chemisorption of sodium oleate on the gibbsite surface. It can be noticed that the component recovery of alumina decreases from $73.9 \%$ at a $\mathrm{pH}$ value of 6 to $57.4 \%$ at a $\mathrm{pH}$ value of 8 , then increases at higher $\mathrm{pH}$ values. 
Table 2: The effect of $\mathrm{pH}$ value on the mass recovery, grade, and component recovery of alumina

\begin{tabular}{|c|c|c|c|c|c|}
\hline \multirow{2}{*}{$\begin{array}{l}\text { Exp. } \\
\text { No. }\end{array}$} & \multirow{2}{*}{$\mathrm{pH}$ value } & \multirow{2}{*}{ Product } & \multirow{2}{*}{$\begin{array}{c}\text { Mass } \\
\text { Recovery, \% }\end{array}$} & \multicolumn{2}{|c|}{ Alumina, $\%$} \\
\hline & & & & Grade & Recovery \\
\hline \multirow{3}{*}{1} & \multirow{3}{*}{6} & Concentrate & 36.9 & 38.1 & 73.9 \\
\hline & & Tailings & 63.1 & 7.9 & 26.1 \\
\hline & & Feed & 100 & 19 & 100 \\
\hline \multirow{3}{*}{2} & \multirow{3}{*}{7} & Concentrate & 34.2 & 35.5 & 63.8 \\
\hline & & Tailings & 65.8 & 10.4 & 36.2 \\
\hline & & Feed & 100 & 19 & 100 \\
\hline \multirow{3}{*}{3} & \multirow{3}{*}{8} & Concentrate & 33.7 & 32.4 & 57.4 \\
\hline & & Tailings & 66.3 & 12.2 & 42.6 \\
\hline & & Feed & 100 & 19 & 100 \\
\hline \multirow{3}{*}{4} & \multirow{3}{*}{9} & Concentrate & 33.7 & 33.5 & 59.3 \\
\hline & & Tailings & 66.3 & 11.6 & 40.7 \\
\hline & & Feed & 100 & 19 & 100 \\
\hline \multirow{3}{*}{5} & \multirow{3}{*}{10} & Concentrate & 35.8 & 35.5 & 666.9 \\
\hline & & Tailings & 64.2 & 9.8 & 33.1 \\
\hline & & Feed & 100 & 19 & 100 \\
\hline \multirow{3}{*}{6} & \multirow{3}{*}{11} & Concentrate & 37.1 & 40.1 & 78.3 \\
\hline & & Tailings & 62.9 & 6.6 & 21.7 \\
\hline & & Feed & 100 & 19 & 100 \\
\hline
\end{tabular}

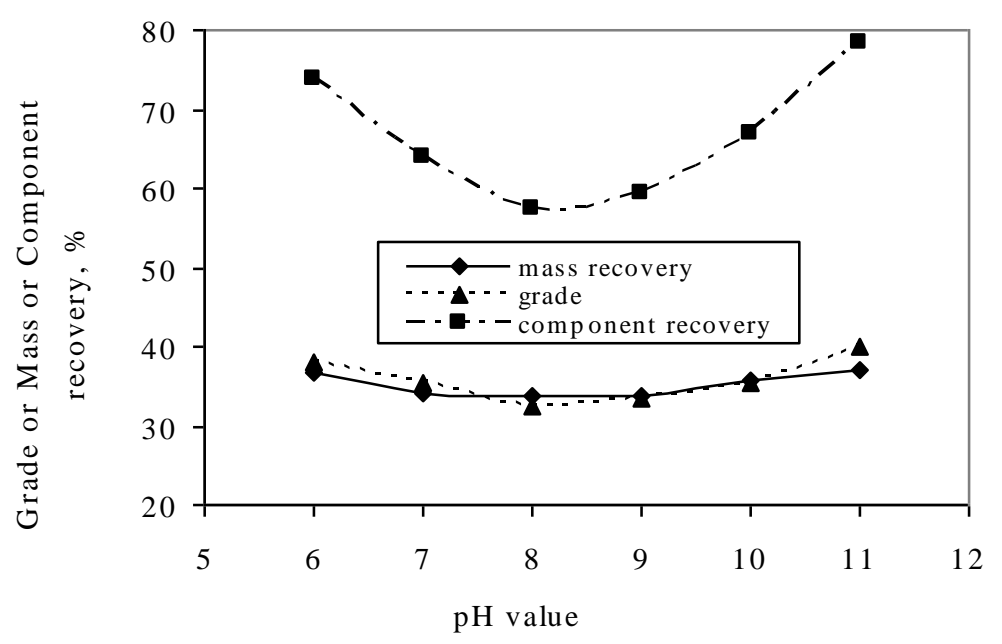

Fig. 5a: Effect of $\mathrm{pH}$ value on the grade, component recovery of alumina in the concentrate, and the mass recovery of concentrate.

Figure $5 \mathrm{~b}$ shows the effect of $\mathrm{pH}$ value on the grade, component recovery of alumina in the tailings, and the mass recovery of tailings. From this figure, it is 
revealed that the component recovery of alumina in the tailings increases from $26.1 \%$ at a $\mathrm{pH}$ value of 6 to $42.6 \%$ at a $\mathrm{pH}$ value of 8 . At $\mathrm{pH}$ values greater than 8 , the component recovery of alumina in the tailings is decreased. The grade of alumina increases from $7.9 \%$ at a $\mathrm{pH}$ value of 6 to $12.2 \%$ at a $\mathrm{pH}$ value of 8 , and then decreases at higher $\mathrm{pH}$ values.

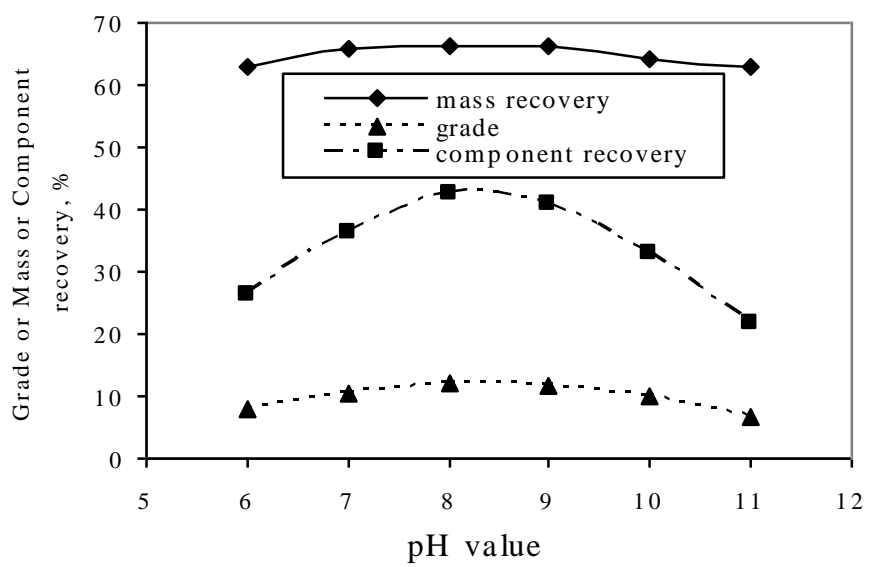

Fig. 5b: Effect of pH value on the grade, component recovery of alumina in tailings, and the mass recovery of tailings.

\subsubsection{Effect of sodium oleate concentration}

Table 3 and Figure 6a illustrate the effect of sodium oleate concentration on the grade, component recovery of alumina in the concentrate, and the mass recovery of concentrate at the optimum value of $\mathrm{pH}$ (11) obtained from the previous experiments. These experiments were carried out at the same conditions of pulp density $(150 \mathrm{~g} / \mathrm{l})$ and particle size $(-200 \mu \mathrm{m})$. From this figure, it is shown that the component recovery of alumina increases from $61.8 \%$ at a concentration of $500 \mathrm{~g} / \mathrm{t}$ sodium oleate to about $79.9 \%$ at a dosage of $2000 \mathrm{~g} / \mathrm{t}$, then decreases at higher collector dosages. The mass recovery of concentrate is increased from $27.6 \%$ to $38.9 \%$ at the same concentrations, and then decreases at collector dosages higher than $2000 \mathrm{~g} / \mathrm{t}$.

The grade of alumina decreases also from $42.5 \%$ to $39.1 \%$ at the same dosages, and then increases at collector dosages higher than $2000 \mathrm{~g} / \mathrm{t}$. There is a gradual increase in the recovery of alumina with the increase of the collector concentration up to a maximum value. This may be due to the rapid reaction, more rapid approach of exchange adsorption equilibrium, and may also be attributed to the powerful action of sodium oleate to produce a water-repulsion and monomolecular layer on particle surfaces thereby imparting hydrophobicity to the particles $[16,17,18]$. An excessive addition of collector dosages leads to an inverse effect and hence decreases the component recovery of alumina. This may be due to the development of collector multilayer on the particles, reducing the proportion of hydrocarbon radicals oriented into the bulk solution. The hydrophobicity of particles is reduced and tends to float other minerals, reducing selectivity and floatability [17]. 
Table 3 : The effect of sodium oleate concentration on the mass recovery, Grade, and component recovery of alumina.

\begin{tabular}{|c|c|c|c|c|c|}
\hline \multirow{2}{*}{ Exp. No. } & \multirow{2}{*}{$\begin{array}{c}\text { Collector } \\
\text { dosage, } g / t\end{array}$} & \multirow{2}{*}{ Product } & \multirow{2}{*}{$\begin{array}{c}\text { Mass } \\
\text { Recovery, \% }\end{array}$} & \multicolumn{2}{|c|}{ Alumina, \% } \\
\hline & & & & Grade & Recovery \\
\hline \multirow{3}{*}{1} & \multirow{3}{*}{500} & Concentrate & 27.6 & 42.5 & 61.8 \\
\hline & & Tailings & 72.4 & 9.9 & 38.2 \\
\hline & & Feed & 100 & 19 & 100 \\
\hline \multirow{3}{*}{2} & \multirow{3}{*}{1000} & Concentrate & 33.7 & 41.1 & 72.9 \\
\hline & & Tailings & 66.3 & 7.8 & 27.1 \\
\hline & & Feed & 100 & 19 & 100 \\
\hline \multirow{3}{*}{3} & \multirow{3}{*}{1500} & Concentrate & 37.1 & 40.1 & 78.3 \\
\hline & & Tailings & 62.9 & 6.6 & 21.7 \\
\hline & & Feed & 100 & 19 & 100 \\
\hline \multirow{3}{*}{4} & \multirow{3}{*}{2000} & Concentrate & 38.9 & 39.1 & 79.9 \\
\hline & & Tailings & 61.1 & 6.3 & 20.1 \\
\hline & & Feed & 100 & 19 & 100 \\
\hline \multirow{3}{*}{5} & \multirow{3}{*}{2500} & Concentrate & 35.9 & 40.1 & 75.5 \\
\hline & & Tailings & 64.1 & 4.5 & 24.5 \\
\hline & & Feed & 100 & 19 & 100 \\
\hline \multirow{3}{*}{6} & \multirow{3}{*}{3000} & Concentrate & 34.4 & 41.1 & 73.7 \\
\hline & & Tailings & 65.6 & 4.9 & 26.3 \\
\hline & & Feed & 100 & 19 & 100 \\
\hline
\end{tabular}

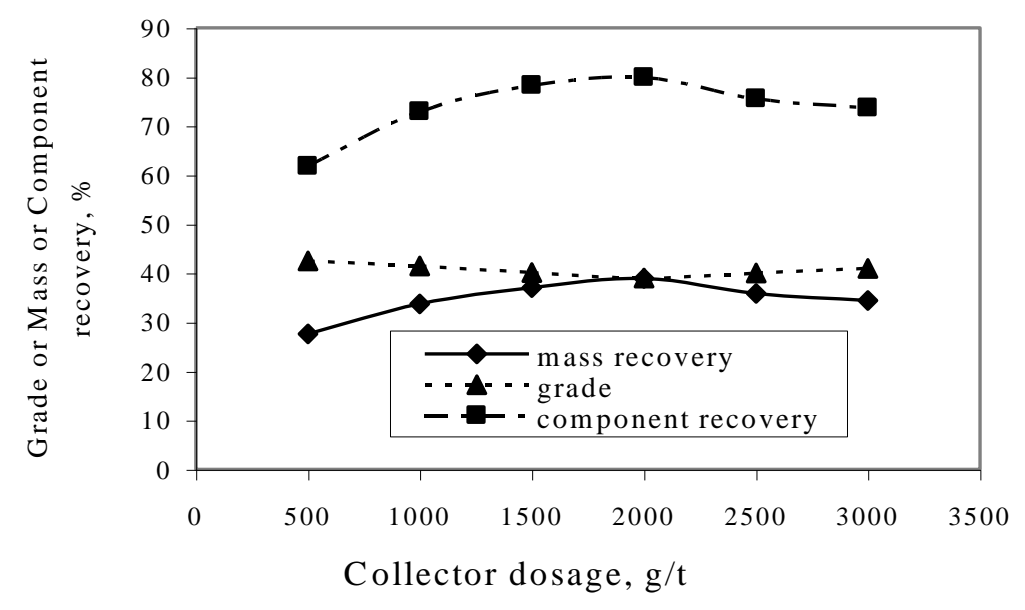

Fig 6a: Effect of sodium oleate dosage on the grade, component recovery of alumina in concentrate, and the mass recovery of concentrate.

Table 3 and Figure $6 \mathrm{~b}$ show the effect of sodium oleate concentration on the grade, component recovery of alumina in tailings, and the mass recovery of tailings. From this figure it is seen that, the component recovery of alumina in tailings decreases from $38.2 \%$ at a concentration of $500 \mathrm{~g} / \mathrm{t}$ of sodium oleate to $20.1 \%$ at $2000 \mathrm{~g} / \mathrm{t}$, then 
increases at higher collector dosages. The mass recovery of tailings decreases from about $72.4 \%$ to $61.1 \%$ at the same collector concentrations, and then increases at collector dosages higher than $2000 \mathrm{~g} / \mathrm{t}$.

The grade of alumina in tailings is decreased from $9.9 \%$ at a concentration of $500 \mathrm{~g} / \mathrm{t}$ to $4.5 \%$ at $2500 \mathrm{~g} / \mathrm{t}$, and then increases at higher collector dosages.

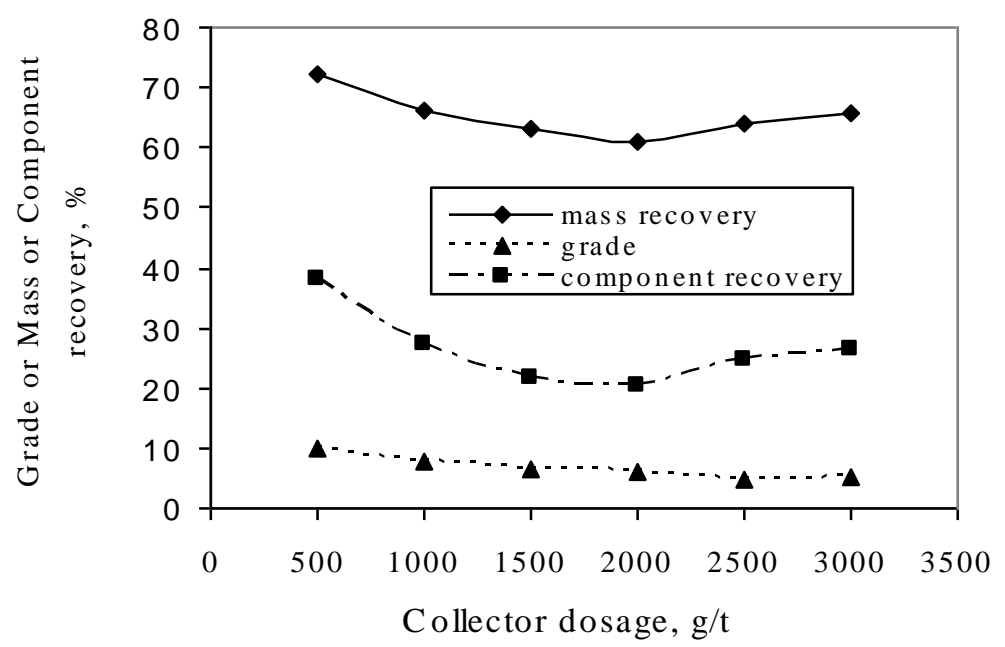

Fig 6b: Effect of sodium oleate dosage on the grade, component recovery of alumina in tailings, and the mass recovery of tailings

\subsubsection{Effect of pulp density}

Table 4 and Figure 7a show the effect of pulp density on the grade, component recovery of alumina in the concentrate, and the mass recovery of concentrate. These experiments were carried out at a $\mathrm{pH}$ value of $11,2000 \mathrm{~g} / \mathrm{t}$ sodium oleate dosage, and with the same above stated particle size $(-200 \mu \mathrm{m})$. From this figure, it is seen that the component recovery increases from $79.9 \%$ at a pulp density of $150 \mathrm{~g} / \mathrm{l}$ to $95.9 \%$ at 350 $\mathrm{g} / \mathrm{l}$, then decreases to $94.9 \%$ at a pulp density of $400 \mathrm{~g} / \mathrm{l}$. The mass recovery of the concentrate is increased from $38.9 \%$ to $66.8 \%$ at the same pulp densities, and then decreased to $59.9 \%$ at $400 \mathrm{~g} / \mathrm{l}$. The grade of alumina in concentrate decreased from $39.1 \%$ to $27.3 \%$ at the same pulp densities, and then increased to $30.1 \%$ at $400 \mathrm{~g} / \mathrm{l}$.

Wills [17] has reported that as a matter of economics, flotation separation must be carried out in as dense a pulp as possible with good selectivity and operating conditions. The denser the pulp, the lesser cell volume required, since the effectiveness of most reagents is a function of their concentrations in solution. The pulp must be diluted enough to permit particle re-arrangement to proceed freely. Over dilution should be avoided as it results in greater amount of water consumption, reagent consumption and more equipment for each tone of ore treated [24]. Therefore, $250 \mathrm{~g} / \mathrm{l}$ is chosen as the optimum value of the pulp density. 
Table 4: The effect of pulp density on the mass recovery, grade, and component recovery of alumina

\begin{tabular}{|c|c|c|c|c|c|}
\hline \multirow{2}{*}{$\begin{array}{l}\text { Exp. } \\
\text { No. }\end{array}$} & \multirow{2}{*}{$\begin{array}{c}\text { Pulp } \\
\text { density, } \mathrm{g} / \mathrm{I}\end{array}$} & \multirow{2}{*}{ Product } & \multirow{2}{*}{$\begin{array}{c}\text { Mass } \\
\text { Recovery, } \%\end{array}$} & \multicolumn{2}{|c|}{ Alumina, \% } \\
\hline & & & & Grade & Recovery \\
\hline \multirow{3}{*}{1} & \multirow{3}{*}{150} & Concentrate & 38.9 & 39.1 & 79.9 \\
\hline & & Tailings & 61.1 & 6.3 & 20.1 \\
\hline & & Feed & 100 & 19 & 100 \\
\hline \multirow{3}{*}{2} & \multirow{3}{*}{200} & Concentrate & 42.1 & 38.6 & 85.5 \\
\hline & & Tailings & 57.9 & 4.8 & 14.5 \\
\hline & & Feed & 100 & 19 & 100 \\
\hline \multirow{3}{*}{3} & \multirow{3}{*}{250} & Concentrate & 44.8 & 38.2 & 90.1 \\
\hline & & Tailings & 55.2 & 3.3 & 9.9 \\
\hline & & Feed & 100 & 19 & 100 \\
\hline \multirow{3}{*}{4} & \multirow{3}{*}{300} & Concentrate & 56.1 & 31.5 & 93.1 \\
\hline & & Tailings & 43.9 & 2.9 & 6.9 \\
\hline & & Feed & 100 & 19 & 100 \\
\hline \multirow{3}{*}{5} & \multirow{3}{*}{350} & Concentrate & 66.8 & 27.3 & 95.9 \\
\hline & & Tailings & 33.2 & 2.3 & 4.1 \\
\hline & & Feed & 100 & 19 & 100 \\
\hline \multirow{3}{*}{6} & \multirow{3}{*}{400} & Concentrate & 59.9 & 30.1 & 94.9 \\
\hline & & Tailings & 40.1 & 2.4 & 5.1 \\
\hline & & Feed & 100 & 100 & 100 \\
\hline
\end{tabular}

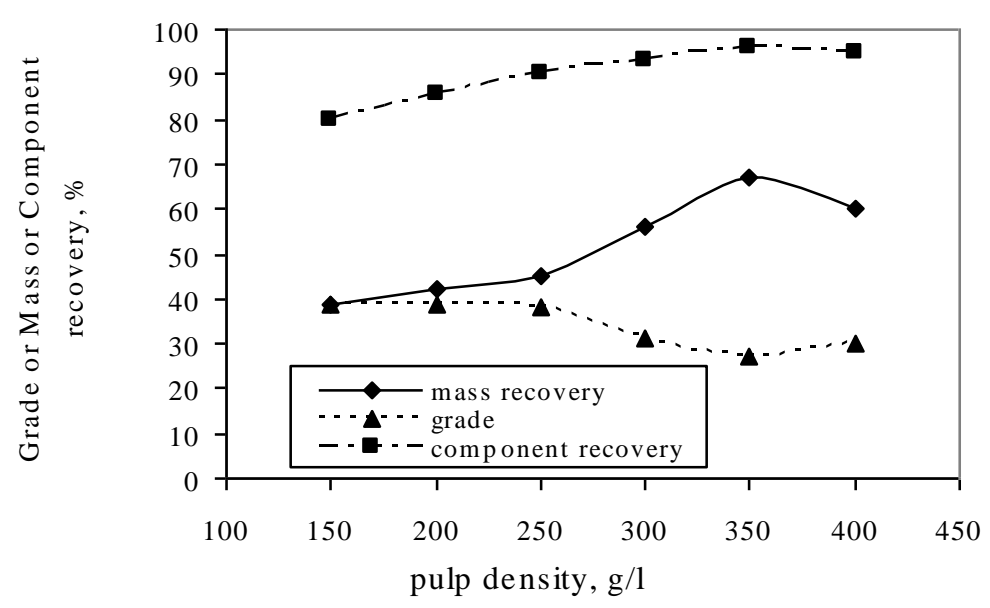

Fig. 7a: Effect of pulp density on the grade, component recovery of alumina in concentrate, and the mass recovery of concentrate. 
Figure $7 \mathrm{~b}$ shows the effect of pulp density on the grade, component recovery of alumina in tailings, and the mass recovery in the tailings. From this figure, it is seen that the component recovery of alumina in tailings decreases from $20.1 \%$ at a pulp density of $150 \mathrm{~g} / 1$ to $4.1 \%$ at $350 \mathrm{~g} / \mathrm{l}$, then increases to $5.1 \%$ at $400 \mathrm{~g} / \mathrm{l}$. The mass recovery of tailings decreases from $61.1 \%$ to $33.2 \%$, and then increases to $40.1 \%$ at the same pulp densities. The grade of alumina in tailings decreases from $6.3 \%$ to $2.3 \%$, and then increases to $2.4 \%$ at the previous pulp densities. The excessive pulp density leads to a low level of mineral extraction in the concentrate and increase the recovery of alumina in the tailings.

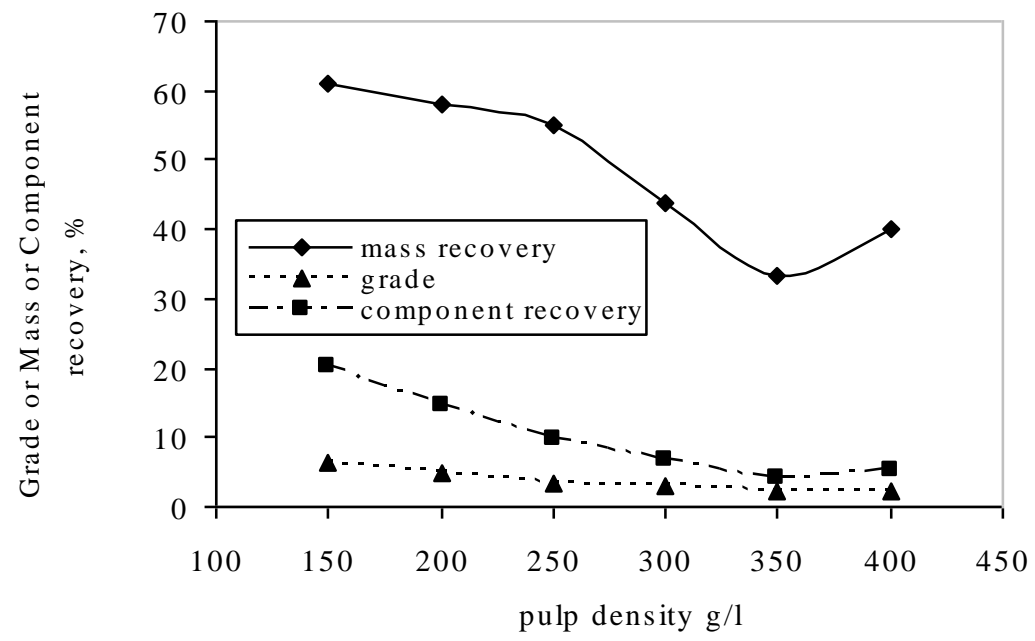

Fig. 7b: Effect of pulp density on the grade, component recovery of alumina in tailings, and the mass recovery of tailings.

\subsubsection{Effect of particle size}

Table 5 and Figure 8a show the effect of particle size on the grade, component recovery of alumina in the concentrate, and the mass recovery of concentrate. These experiments were executed at a $\mathrm{pH}$ value of $11,2000 \mathrm{~g} / \mathrm{t}$ sodium oleate concentration, and a pulp density of $250 \mathrm{~g} / \mathrm{l}$. From this figure, it is seen that, the component recovery of alumina increases from $69.1 \%$ at a particle size of $(-200+160) \mu \mathrm{m}$ to $97.6 \%$ at $(-80+63) \mu \mathrm{m}$, then decreases to $89.9 \%$ at $(-63+0) \mu \mathrm{m}$.

The mass recovery of concentrate increases from $22.4 \%$ to $64.7 \%$ at the same particle sizes, and then decreases to $54.7 \%$ at $(-63+0) \mu \mathrm{m}$. The grade of alumina in concentrate decreases from $46.9 \%$ at a particle size of $(-200+160) \mu \mathrm{m}$ to $33.2 \%$ at $(-80+63) \mu \mathrm{m}$, and then increases to $34.5 \%$ at $(-63+0) \mu \mathrm{m}$.

Particle liberation plays an important role in the flotation process, where particles of various sizes do not float equally well. Increasing particle sizes may result in longer induction times, a commensurate deterioration in floatability, as well as, it is expected that the coarser particles would tend to settle in the lower part of the flotation cell $[19,20]$. The recovery is maximum for some intermediate size ranges, with a 
distinct fall towards the extreme course and extreme fine ranges [16,21]. Vijayendra [16] reported that, the particles should not be overground, as the recovery and selectivity decrease markedly if the particles are finer than 5 to 10 microns.

Table 5 : Effect of particle size on the mass recovery, grade, and component recovery of alumina.

\begin{tabular}{|c|c|c|c|c|c|}
\hline \multirow{2}{*}{$\begin{array}{l}\text { Exp. } \\
\text { No. }\end{array}$} & \multirow{2}{*}{$\begin{array}{c}\text { Particle size, } \\
\mu \mathrm{m}\end{array}$} & \multirow{2}{*}{ Product } & \multirow{2}{*}{$\begin{array}{c}\text { Mass } \\
\text { Recovery, \% } \\
\end{array}$} & \multicolumn{2}{|c|}{ Alumina, $\%$} \\
\hline & & & & Grade & Recovery \\
\hline \multirow{3}{*}{1} & \multirow{3}{*}{$-200+160$} & Concentrate & 22.4 & 46.9 & 69.1 \\
\hline & & Tailings & 77.6 & 6.1 & 30.9 \\
\hline & & Feed & 100 & 15.2 & 100 \\
\hline \multirow{3}{*}{2} & \multirow{3}{*}{$-160+125$} & Concentrate & 29.8 & 44.5 & 85.5 \\
\hline & & Tailings & 70.2 & 2.5 & 14.5 \\
\hline & & Feed & 100 & 15.5 & 100 \\
\hline \multirow{3}{*}{3} & \multirow{3}{*}{$-125+100$} & Concentrate & 40.6 & 41.6 & 92.9 \\
\hline & & Tailings & 59.4 & 1.8 & 7.1 \\
\hline & & Feed & 100 & 18.2 & 100 \\
\hline \multirow{3}{*}{4} & \multirow{3}{*}{$-100+80$} & Concentrate & 51.5 & 40.1 & 96.1 \\
\hline & & Tailings & 48.5 & 1.7 & 3.9 \\
\hline & & Feed & 100 & 21.5 & 100 \\
\hline \multirow{3}{*}{5} & \multirow{3}{*}{$-80+63$} & Concentrate & 64.7 & 33.2 & 97.6 \\
\hline & & Tailings & 35.3 & 1.5 & 2.4 \\
\hline & & Feed & 100 & 22 & 100 \\
\hline \multirow{3}{*}{6} & \multirow{3}{*}{$-63+0$} & Concentrate & 54.7 & 34.5 & 89.9 \\
\hline & & Tailings & 45.3 & 4.7 & 10.1 \\
\hline & & Feed & 100 & 21 & 100 \\
\hline
\end{tabular}



Fig. 8a: Effect of particle size on the grade, component recovery of alumina in concentrate, and the mass recovery of concentrate. 
Figure $8 \mathrm{~b}$ shows the effect of particle size on the grade, component recovery of alumina in tailings, and the mass recovery of tailings. From this figure, it is seen that, the component recovery of alumina decreases from $30.9 \%$ at a particle size of ($200+160) \mu \mathrm{m}$ to $2.4 \%$ at $(-80+63) \mu \mathrm{m}$, then increases to $10.1 \%$ at $(-63+0) \mu \mathrm{m}$. The mass recovery of tailings decreases from $77.6 \%$ to $35.3 \%$ at the same particle sizes, then increases to $45.3 \%$ at a particle size of $(-63+0) \mu \mathrm{m}$. The grade of alumina in tailings decreases from $6.1 \%$ at a particle size of $(-200+160) \mu \mathrm{m}$ to $1.5 \%$ at $-80+63$ $\mu \mathrm{m}$, then increases to $4.7 \%$ at $(-63+0) \mu \mathrm{m}$. It can be noticed also that the rise in tailing assays in the coarser fractions might be read to denote simply a progressive decrease in liberation and failure of coarse free mineral to float.

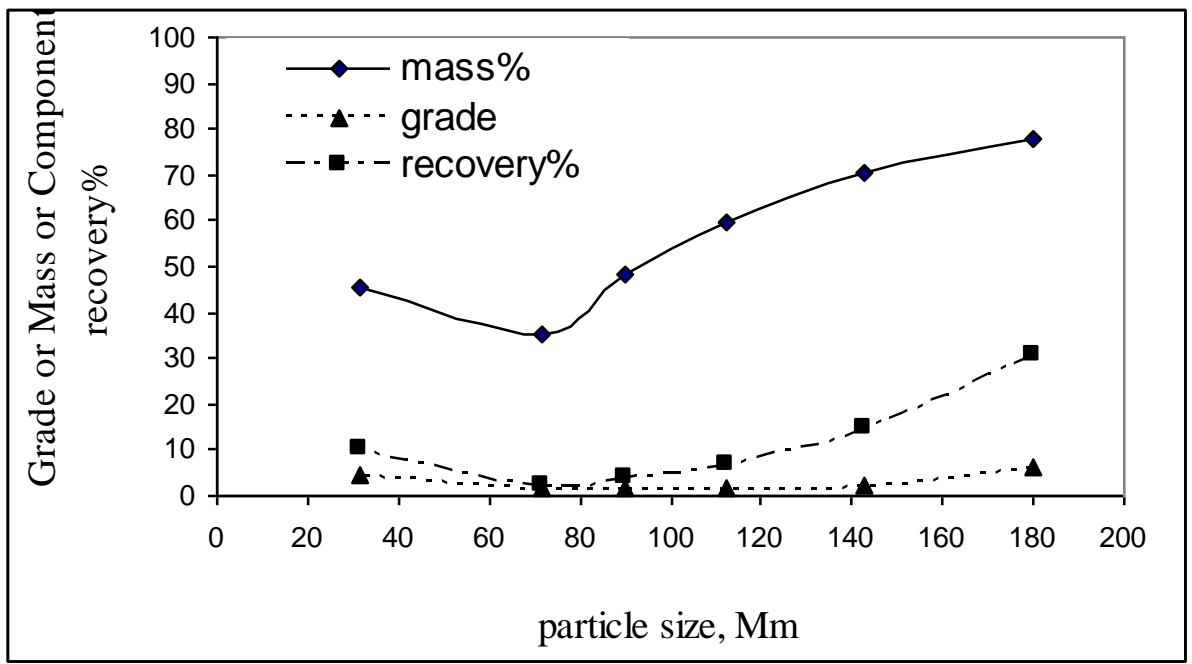

Fig. 8b: Effect of particle size on the grade, component recovery of alumina in tailings, and the mass recovery of tailings.

\section{CONCLUSIONS}

From the obtained results the following conclusions can be drawn:

1. Cationic collectors can not be applied for the gibbsite ore due to the presence of significant amounts of quartz.

2. The optimum operating conditions were as follows: sodium oleate dosage $=$ $2000 \mathrm{~g} / \mathrm{t}$, pulp density $=250 \mathrm{~g} / \mathrm{l}, \mathrm{pH}=11$ and a particle size of $(-100+80) \mu \mathrm{m}$.

3. At optimum operating variables of flotation process, a concentrate of $51.5 \%$ mass recovery containing $40.1 \%$ alumina grade with a component recovery $96.1 \%$ was obtained. The assays of other ore constituents in the final concentrate were as follows: $5.9 \% \mathrm{SiO} 2,4.8 \% \mathrm{CaO}, 5.4 \% \mathrm{Fe} 2 \mathrm{O} 3,3.2 \% \mathrm{P} 2 \mathrm{O} 5$, $3.5 \% \mathrm{MnO}, 1.3 \% \mathrm{~K} 2 \mathrm{O}, 1.2 \% \mathrm{Na} 2 \mathrm{O}, 2.7 \%$ traces, and $31.4 \%$ loss on ignition. The component recoveries of $\mathrm{SiO} 2, \mathrm{CaO}, \mathrm{Fe} 2 \mathrm{O} 3, \mathrm{P} 2 \mathrm{O} 5, \mathrm{MnO}, \mathrm{K} 2 \mathrm{O}, \mathrm{Na} 2 \mathrm{O}$, and traces in the final concentrate were $21.4 \%, 17.5 \%, 21.2 \%, 38.4 \%, 42.9 \%$, $75.3 \%, 89.6 \%$, and $86.9 \%$, respectively.

4. The final product is suitable for many industrial purposes such as aluminous chemicals (aluminum sulfate and sodium aluminate are used for water 
treatment and aluminum chloride is used in refining crude petroleum), abrasive products (coated abrasives, sharpening stones and grinding wheels). The final product may be also applied for alumina refractories and alumina extraction after its processing by Bayer process.

\section{REFERENCES}

1. Helena, S. S., Teresa, W. C., Persio, S. S., and Perdo, K. K., "Thermal phase sequences in gibbsite/kaolinite clay: electron microscopy studies", Ceramics International, Vol. 31, pp. 1077-1084, 2005.

2. Burkin, A.R., "Production of aluminum and alumina", John \& Sons, New York, pp. 3-13, 1987.

3. O'Connor, D.J., "Alumina extraction from non bauxitic materials", AluminumVerlag GmbH, Germany, pp. 1-10, 1988.

4. Bittencourt, L.R.M., Lin, C.L., and Miller, J.D., "Flotation recovery of high purity gibbsite concentrates from a Brazilian bauxite ore", In: Advanced Materials-Application Mineral and Metallurgical Processing Principles, Society of Mining Engineers of AIM, pp. 77-85, 1990.

5. Zhenghe, X., Plitt, V., and Liu, Q., "Recent advances in reverse flotation of diasporic ores-A Chinese experience", Minerals Engineering, Vol. 17, pp. 10071015, 2004.

6. Hinds, S.A., Husain, K., and Liu, N., "Beneficiation of bauxite tailings", Light Met., Vol. 54, pp. 17-30, 1985.

7. Andreev, P.I., Anishchenko, N.M., and Mishakenkova, N.P., "Mechanism of the action of amines during the flotation of bauxite ore minerals", Tsvetnye Metally, Vol. 18, pp. 13-17, 1975.

8. Bulut, G. and Yurtsever, C., "Flotation behaviour of bitlis kyanite ore", Int. J. Miner. Process., Vol. 73, pp. 29- 36, 2004.

9. Doss, S.K., "Adsorption of dodecyltrimethylammonium chloride on alumina and its relation to oil-water flotation", Min. Process. Extr. Metall., C195-C199, 1976.

10. Wang, Y., Hu, Y., He, P., and Gu, G., "Reverse flotation of silicates from diasporic-bauxite", Minerals Engineering, Vol. 17, pp. 63-68, 2004.

11. Marie, C.J., Fabien, G., and Bernard, H., "Limitations of potentiometric studies to determine the surface charge of gibbsite $\gamma-\mathrm{Al}(\mathrm{OH})_{3}$ particles", Journal of Colloid and Interface Science, Vol. 6, pp. 1-11, 2005.

12. Murray, B.M., "Adsorption of fatty acid spin probes on amorphous alumina", Journal of Colloid and Interface Science, Vol. 76, pp. 393-398, (1980).

13. Hu, Y. and Dai, J., "Hydrophobic aggregation of alumina in surfactant solution", Minerals Engineering, Vol. 16, pp. 1167-1172, 2003.

14. Vamvuka, D. and Agridiotis, V., "The effect of chemical reagents on lignite flotation", Int. J. Min. Process., Vol. 61, pp. 209-224, 2000. 
15. Ye, H. and Matsuoka, I., "Oleate flotation of dickite from quartz with diluted $\mathrm{HCl}$ preconditioning. I. Effect of $\mathrm{HCl}$ preconditioning", Int. J. Min. Process., Vol. 40, pp. 83-98, 1993.

16. Vijayendra, H.G., "Handbook on mineral dressing", 2nd ed., Vikas, New Delhi, pp. 195-210, 1995.

17. Wills, B.A., "Mineral Processing technology", Elsevier Ltd., 7th ed., pp. 283293, 2006.

18. Ahmed, M.M., "Kinetics of Magara coal flotation", M.Sc. Thesis, Assuit University, Egypt, pp. 73-78, 1995.

19. Feng, D. and Aldrich, C., "Effect of particle size on flotation performance of complex sulfide ores", Minerals Engineering, Vol. 12, pp. 721-731, 1999.

20. Zheng, X., Franzidis, J.P., Jounson, N.W., and Manlaping, E.V., "Modeling of entrainment in industrial flotation cells: the effect of solid suspension", Minerals Engineering, Vol. 18, pp. 51-58, 2005.

21. Ucurum, M. and Bayat, O., "Effects of operating variables on modified flotation parameters in the mineral separation", Separation Purification Technology, In Press 2006.

\section{الوصول للحالة المثلى لتعويم الالومينا من خام طقلة جنوب غرب سيناء الحاملة

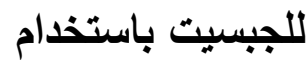

Sodium Oleate

في هذا البحث تم دراسة تأثثر Sodium oleate كمجمع لتعويم الألو مينا المتواجدة في خام الطفلة الحاملة للجبسيت بجنوب غرب سيناء بهدف تركيز الالومينا في خام الطفلة الحاملة للجبسيت للحصول على منتج بمواصفات مناسبة لانتاج الالومينا عالية التركيز ومناسبة للصناعات المختلفة. زيادة تركيز الالومينا بها لكى تكون مناسبه للاخول فى عملية Bayer والتطبيقات الصناعيه المختلفه.

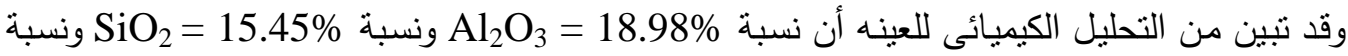
$\mathrm{MnO}=12.87 \%$ و و نسبة $\mathrm{PaO}_{2} \mathrm{~F}_{2} \mathrm{O}_{3}=5.74 \%$ نسبة $12.83 \%$

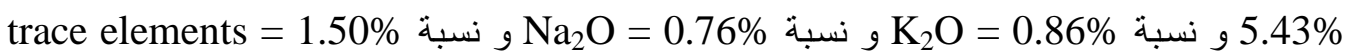
و نسبة فاقد الحرق = 23.65\%.

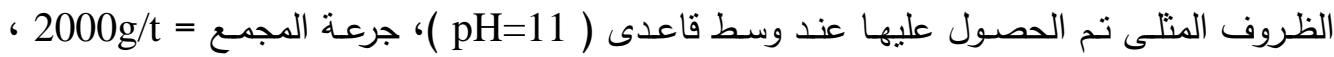

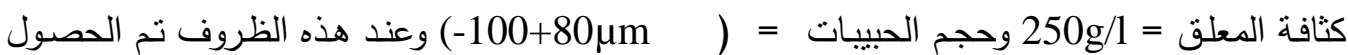
على ركاز بالمواصفات الاتيه: نسبة $1 \%$

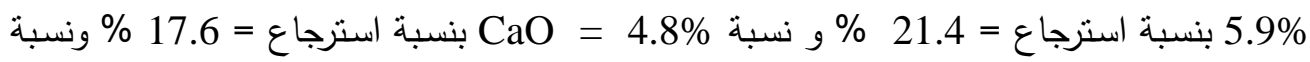
Pنسبة استرجاع = $\mathrm{Fe}_{2} \mathrm{O}_{3}=5.4 \%$ بنسبة استرجاع = $38.5 \%$ و نسبة 38.4 و و 
نسبة

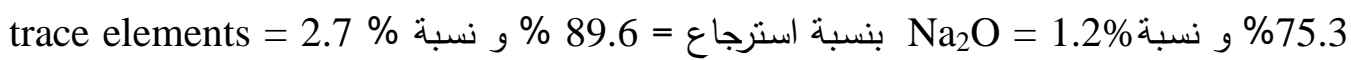
بنسبة استرجاع = 86.9 \% . وقد تم الحصول على 51.5\% استرجاع للكتله بالنسبه لكنلة الخـام

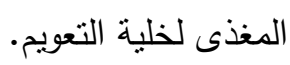
ويمكن استخدام هذا المنتج في العديد من الأغراض الصناعية مثل المواد الكيميائية المستخدمة في معالجة المياه (minatesodium alu) و و و المواد المستخدمة في تكرير البترول مثل ال aluminum chloride و كذلك الصنفرة و صناعة الحراريات وصناعة الألومنيوم بعد و ولند Bayer تركيزها بطريقة 